\title{
A Study on the Phylogeny of the Dyer's Woad Rust Fungus and Other Species of Puccinia from Crucifers
}

\author{
Bradley R. Kropp, Dane R. Hansen, Paul G. Wolf, Karen M. Flint, and Sherman V. Thomson
}

Department of Biology, Utah State University, Logan 84322.

Accepted for publication 21 February 1997.

\begin{abstract}
Kropp, B. R., Hansen, D. R., Wolf, P. G., Flint, K. M., and Thomson, S. V. 1997. A study on the phylogeny of the dyer's woad rust fungus and other species of Puccinia from crucifers. Phytopathology 87:565-571.

The identity of a Puccinia species occurring on the introduced weed dyer's woad (Isatis tinctoria) was studied using sequences from the internal transcribed spacer of the nuclear ribosomal DNA. The relationship of this fungus to other Puccinia species occurring on the family Brassicaceae in Europe and North America was examined, and we tested the hypothesis that $P$. thlaspeos and P. monoica are correlated species. The data suggest that the Puccinia species from dyer's woad is closely related
\end{abstract}

ABSTRACT

Several rust fungi have been assessed for use as biocontrol agents against weeds. These fungi vary in their effectiveness, but some show considerable promise (22). Rust fungi such as Puccinia chrondrillina appear to have the most potential for biological control, because they are easily dispersed and can infect plants under a range of conditions. These rust fungi may also reduce seed production and lower the ability of perennial plants to overwinter (10).

A species of Puccinia with excellent biocontrol potential was found on the introduced weed dyer's woad (Isatis tinctoria L.) in southern Idaho in 1978 (18). Although it does not appear to kill dyer's woad, infections by this fungus are systemic and cause stunting and severe malformation. In addition, infected plants produce very few seed and, because of this, the fungus is being intensively studied as a potential biological control agent for dyer's woad. Since its discovery, the fungus has spread from southern Idaho into portions of northern Utah.

Dyer's woad, a member of the family Brassicaceae, was brought to North America from Europe during the colonial period and is thought to have come to the western United States in the early 1900s $(4,23)$. Under western conditions, it aggressively competes with native vegetation and has become a serious problem on rangeland and in agricultural areas. Because much of the rangeland affected by this weed is inaccessible, chemical control may be difficult or impossible. Thus, the Puccinia species attacking dyer's woad may provide one of very few options for controlling this weed.

Its use as a biological control agent requires a thorough understanding of its identity. The fungus has been tentatively identified as P. thlaspeos C. Schub., and most of its characteristics correspond to the description of this species (1). It is an autoecious,

Corresponding author: B. R. Kropp; E-mail address: brkropp@cc.usu.edu

Publication no. P-1997-0325-01R

(C) 1997 The American Phytopathological Society to the North American species $P$. consimilis and may be derived from an indigenous strain of $P$. consimilis that switched hosts. Thus, the Puccinia species from dyer's woad is probably native to North America and is unlikely to cause disease epidemics on indigenous plants if used as a biological control agent against dyer's woad. $P$. thlaspeos appears to be polyphyletic and, therefore, $P$. thlaspeos and P. monoica do not appear to be correlated species. Additional DNA sequence data will be needed to clarify further the phylogeny of Puccinia species on the family Brassicaceae.

Additional keywords: noxious weed, PCR, rust fungi.

microcyclic species. The teliosori are usually hypophyllous, and the teliospores fit the description for $P$. thlaspeos, with a persistent pedicel, a thickened apex, the pore of the upper cell at the apex, and the pore of the lower cell at the septum (Fig. 1). However, there are a few characters inconsistent with $P$. thlaspeos. Spermatia are abundant on infected dyer's woad prior to the appearance of teliosori; yet Arthur (1) indicates that spermatia are not seen on collections of $P$. thlaspeos and are probably not formed by this species. In addition, $P$. thlaspeos has been reported to occur on members of several genera in the family Brassicaceae, but not on Isatis $(1,7)$. Dyer's woad plants infected with rust have been found sharing sites with healthy plants of Arabis drummondi, Arabis sp., Descurainia pinnata (Walter) Britton, Erysimum sp., and Thlaspi sp., which are reported hosts of P. thlaspeos (7; S. V. Thomson, personal communication). Thus, the identity of the rust fungus occurring on dyer's woad needs further clarification.

In many cases, host identification and morphology of the teliospores are the only characteristics available for studying the taxonomy of microcyclic rust fungi. A range of potential hosts for the dyer's woad rust was examined in the initial part of this study. But, additional characters may also be obtained from DNA sequence data, and the analysis of sequence data has been shown to be useful in studies of the relationships among species of Puccinia (26). The objectives of the present work were to use host range data and DNA sequences to (i) examine the relationship of the fungus on dyer's woad to $P$. thlaspeos, (ii) test the hypothesis that $P$. thlaspeos and $P$. monoica are correlated species, (iii) gain a better understanding of the relationship between the rust fungus on dyer's woad and other members of Puccinia occurring on the family Brassicaceae, and (iv) understand better whether the fungus on dyer's woad is indigenous or introduced.

\section{MATERIALS AND METHODS}

Host range studies. The cruciferous species Thlaspi montanum L., Smelowskia calycina (Stephenson ex Willd.) C.A. Mey., D. pinnata, T. arvense L., Brassica napus L. (canola 'Westar'), and B. campestris L. (canola 'Goldrush') were selected for a test of 
the host range of dyer's woad rust. T. montanum, S. calycina, and $D$. pinnata are described as hosts of $P$. thlaspeos (7). The two varieties of canola were tested because canola is grown in some regions where dyer's woad is a noxious weed. T. arvense, which is an introduced plant in the Rocky Mountain region, was included because it occurs in woad-infested areas.

In spring of 1993, each of the above species and dyer's woad were grown in 4-inch plastic pots and exposed to rust infection at a field site alongside naturally occurring, rusted dyer's woad bearing teliosori. Thirty pots containing one or two plants were used for each species. They were watered by hand as needed, and the annual plants (B. napus, B. campestris, D. pinnata, and T. arvense) remained in the field until they bolted and began to senesce. The perennial plants (T. montanum and S. calycina) and dyer's woad remained in the field until the indigenous rusted woad began to senesce, and they were then placed in a woad-free area for observation and overwintering. Plants that developed symptoms of rust were recorded and removed as soon as symptoms were visible. Overwintered plants were observed for rust symptoms through late summer of 1994. In spring of 1994, the experiment was repeated using 30 pots each of $S$. calycina, D. pinnata, both canolas, and dyer's woad. There were six pots each of $T$. montanum and $T$. arvense. Twenty-two pots containing dyer's woad were added to the site after hail damaged the original plants. Overwintered plants were observed for symptoms of rust infection through late summer of 1995.

Fungal material. The relationship of the dyer's woad rust fungus to $P$. monoica Arth., $P$. consimilis Ellis \& Everh., and $P$. thlaspeos was studied, because these species are considered to be closely related and may be correlated species $(1,5)$. P. drabae F. Rudolphi, $P$. aberrans Peck, and $P$. codyi Savile were also studied, because they occur on the family Brassicaceae and are not part of the above group of correlated species. P. caricina DC., which occurs on members of the family Cyperaceae, was used as the outgroup.

Two samples of the Puccinia on dyer's woad and a collection of $P$. caricina on Carex rostrata Stokes were collected from sites in northern Utah and deposited in the Intermountain Herbarium at Utah State University. All other specimens were obtained as loans from the herbaria listed in Table 1. The presence of aecia, telia, and spermatia was determined by examining herbarium specimens (Table 2) under a high-powered dissecting microscope.

DNA isolation, amplification, and sequencing. Small pieces of leaf tissue 2 to $3 \mathrm{~mm}$ in diameter, bearing either teliosori or aecia (depending on the species of Puccinia), were removed from the herbarium specimens and placed in a $1.5-\mathrm{ml}$ microcentrifuge

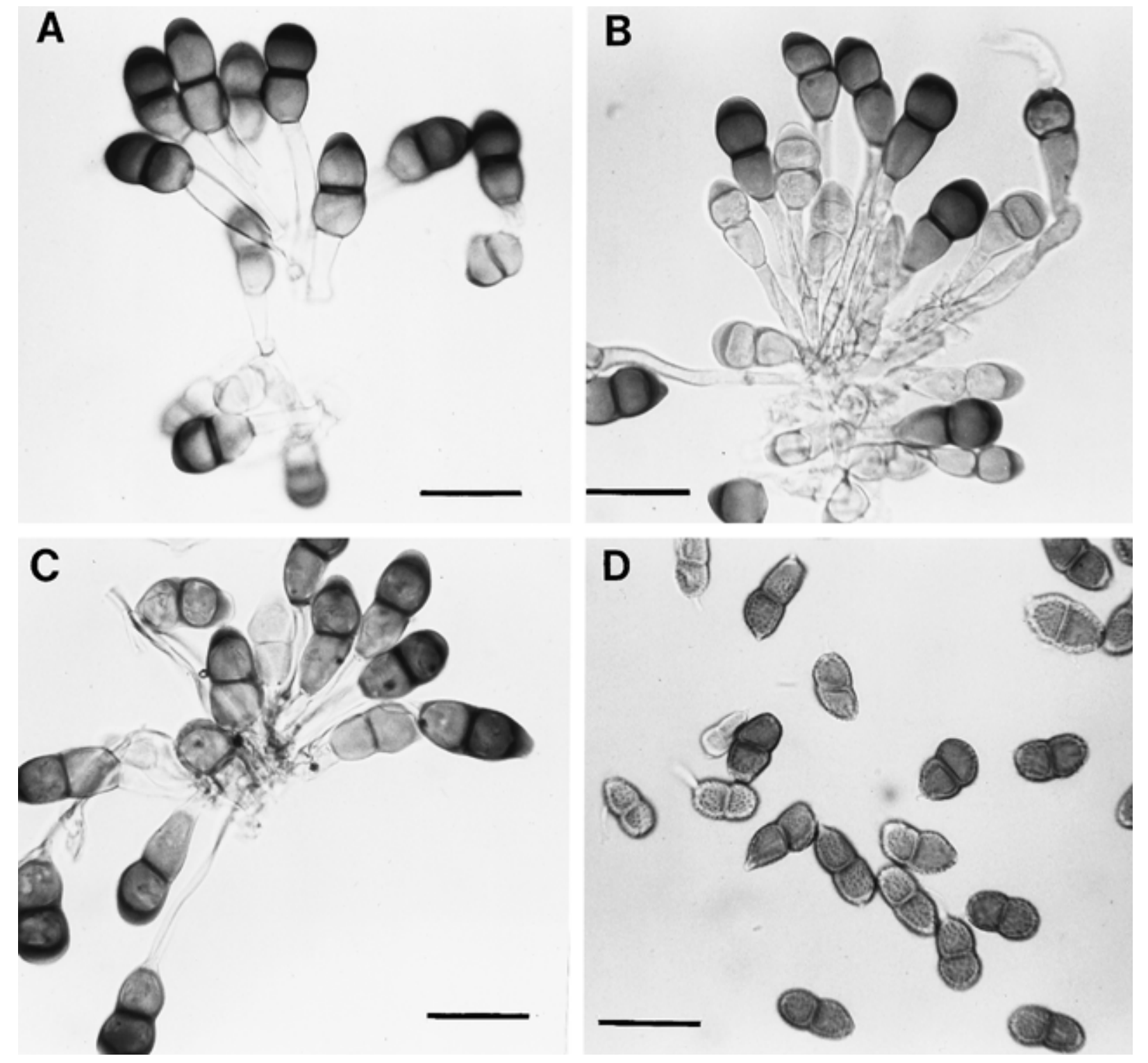

Fig. 1. Teliospores representing ornamented and unornamented members of the genus Puccinia occurring on crucifers. A, Puccinia sp. from dyer's woad; B, $P$. thlaspeos; C, P. consimilis; and D, P. drabae. Bar $=40 \mu \mathrm{M}$. 
tube. DNA was extracted using the method of Kropp et al. $(14,15)$. Liquid nitrogen was added to the microcentrifuge tubes, and the leaf tissue was crushed to powder using a glass rod. Five hundred microliters of extraction buffer $(0.7 \mathrm{M} \mathrm{NaCl}, 0.05 \mathrm{M}$ Tris- $\mathrm{HCl}$ [pH 8], $0.01 \mathrm{M}$ EDTA, 1\% $\beta$-mercaptoethanol, and $1 \%$ cetyltrimethylammonium bromide $[\mathrm{CTAB}]$ ) was added to each crushed sample and incubated for $30 \mathrm{~min}$ at $60^{\circ} \mathrm{C}$. An equal or greater volume of chloroform/isoamyl alcohol (24:1 by vol) was added to each tube. The mixture was then emulsified using a vortex and centrifuged at $11,750 \times g$ for $5 \mathrm{~min}$. The supernatant was collected, nucleic acids were precipitated with isopropyl alcohol and centrifuged at $11,750 \times g$ for $5 \mathrm{~min}$, and each pellet was washed in $80 \%$ ethyl alcohol (EtOH). After being recentrifuged, pellets were dried at room temperature overnight, resuspended in 20 to $40 \mu$ of Tris-EDTA buffer ( $\mathrm{pH} 8$ ), and stored at $-20^{\circ} \mathrm{C}$.

Sequences of the internal transcribed spacer (ITS) region from nuclear ribosomal DNA were obtained for analysis using polymerase chain reaction (PCR). Four primers, corresponding to conserved regions of the $5^{\prime}$ end of the large ribosomal subunit or to the $3^{\prime}$ end of the small ribosomal subunit, were used in different combinations to amplify the entire ITS region. The two primers corresponding to the large ribosomal subunit were Rust 1 (5'-GCT TAC TGC CTT CCT CAA TC-3') (17) and ITS4 (5'-TCC TCC GCT TAT TGA TAT GC-3') (24). The primers corresponding to sequences on the small ribosomal subunit were ITS5 (5'-GGA AGT AAA AGT CGT AAC AAG G-3') (24) and ITS1F (5'-CTT GGT CAT TTA GAG GAA GTA A-3') (8). In cases in which amplification was difficult, primers ITS5 and ITS4 were used as nested primers after a preliminary amplification using either ITS1F and Rust 1 or ITS5 and Rust 1.

Amplifications were done using 100- $\mu$ l PCR reactions each containing $50 \mathrm{mM} \mathrm{KCl}, 10 \mathrm{mM}$ Tris- $\mathrm{HCl}(\mathrm{pH} \mathrm{9.0),} \mathrm{0.1 \%} \mathrm{Triton}$ $\mathrm{X}-100,2.5 \mathrm{mM} \mathrm{MgCl} \mathrm{m}_{2}, 0.2 \mathrm{mM}$ of each dNTP, $0.1 \mu \mathrm{M} 5^{\prime}$-primer, $0.1 \mu \mathrm{M} 3$ '-primer, and 2.4 units Taq DNA polymerase. Four microliters of diluted DNA extract was used per reaction. The DNA extract was usually diluted 1:10 before use, but dilutions of 1:100 and 1:1,000 were used when necessary to achieve amplification. The exact concentration of the template was not determined. Mineral oil was added to each tube to prevent evaporation, and amplifications were done in a Perkin-Elmer DNA thermal cycler (Perkin-Elmer Corp., Norwalk, CT). For the reactions involving most of the primer combinations, the amplification parameters of Kropp et al. (15) were used. However, for amplifications using primer pair ITS1F and Rust 1, the amplification parameters of Gardes and Bruns (8) were modified for use as follows: denaturation at $95^{\circ} \mathrm{C}(35 \mathrm{~s})$, annealing at $45^{\circ} \mathrm{C}(55 \mathrm{~s})$, and extension at $72^{\circ} \mathrm{C}(45 \mathrm{~s})$ for 13 cycles; denaturation at $95^{\circ} \mathrm{C}(35 \mathrm{~s})$, annealing at $45^{\circ} \mathrm{C}(55 \mathrm{~s})$, and extension at $72^{\circ} \mathrm{C}(120 \mathrm{~s})$ for an additional 13 cycles; denaturation at $95^{\circ} \mathrm{C}(35 \mathrm{~s})$, annealing at $45^{\circ} \mathrm{C}(55 \mathrm{~s})$, and extension at $72^{\circ} \mathrm{C}(180 \mathrm{~s})$ for nine cycles; and a final extension at $72^{\circ} \mathrm{C}$ for $10 \mathrm{~min}$.

After amplification, the entire volume of each reaction was placed as a droplet onto a Parafilm strip. The mineral oil was removed by tilting the Parafilm and allowing the droplet to roll along its surface, leaving the oil behind as it moved (25). The double-stranded amplification product was then purified using Wizard PCR Preps DNA purification system (Promega Corp., Madison, WI). Sequences were obtained from the purified amplification product using the dye terminator method with an Applied Biosystems, Inc., model 373A DNA sequencer (Foster City, CA). ITS I was sequenced using primer ITS5, and ITS II was sequenced using primer ITS4. To enable ITS I and II to be sequenced in both directions, two internal primers were made using preliminary sequence data containing the $5.8 \mathrm{~s}$ gene. These primers corresponded to sequences in the $5.8 \mathrm{~s}$ gene and were designated Rust 2 (5'-TTT CAC TGT GTT CTT CAT C-3') and Rust 3 (5'GAA TCT TTG AAC GCA CCT TG-3'). Primers Rust 2 and Rust 3 were used to sequence ITS I and ITS II, respectively, and the two reverse sequences for each region were used as a comparison to insure that the data were correct.

Alignment of sequences and phylogenetic analysis. Sequences were entered into the GCG Wisconsin Sequence Analysis Package (Genetic Computer Group, Inc., Madison, WI) and aligned visually. In cases in which there was a choice of substitutions, transitions (i.e., purine for a purine or pyrimidine for a pyrimidine) were preferred over transversions.

Our data set included several insertion/deletions (indels) that may be informative for inferring phylogenies. Therefore, we coded indels so they could be treated as characters. Single-nucleotide indels were coded with gaps (as a fifth character), and multibase indels were treated as additional characters $(0=$ gap, 1 = no gap) appended to the end of the data matrix. Within the main

TABLE 1. Collections of Puccinia species from which sequence data were obtained

\begin{tabular}{|c|c|c|c|c|}
\hline Species & Herbarium & Gene bank number & Origin and date & Host \\
\hline Puccinia sp. & F00568 (UTC $\left.{ }^{a}\right)$ & U88212 & Utah, United States (1994) & Isatis tinctoria \\
\hline Puccinia sp. & F00567 (UTC) & U88213 & Utah, United States(1995) & Isatis tinctoria \\
\hline Puccinia sp. & AN025349 (ARIZ) & U88214 & Idaho, United States (1983) & Isatis tinctoria \\
\hline P. thlaspeos & US-0107511 (BPI) & U88218 & Switzerland (1924) & Arabis hirsuta \\
\hline P. thlaspeos & US-0107513 (BPI) & U88219 & Sweden (1958) & Arabis hirsuta \\
\hline P. thlaspeos & AN025351 (ARIZ) & U88220 & Colorado, United States (1973) & Thlaspi alpestre $e^{\mathrm{b}}$ \\
\hline P. thlaspeos & AN025352 (ARIZ) & U88221 & Colorado, United States (1973) & Thlaspi alpestre \\
\hline P. thlaspeos & AN025354 (ARIZ) & U88222 & Wyoming, United States (1982) & Arabis microphylla \\
\hline P. thlaspeos & US-0107498 (BPI) & U88217 & Alaska, United States (1904) & Arabis ambigua \\
\hline$P$. consimilis & US-0058385 (BPI) & U88215 & Wyoming, United States(1898) & Sisymbrium linifolium \\
\hline P. consimilis & US-0058382 (BPI) & U88216 & Montana, United States (1889) & Sisymbrium linifolium ${ }^{\mathrm{b}}$ \\
\hline P. monoica & AN024025 (ARIZ) & U88224 & Colorado, United States(1979) & Arabis retrofracta \\
\hline P. monoica & AN024026 (ARIZ) & U88225 & Arizona, United States (1973) & Arabis perennans \\
\hline P. monoica & AN024032 (ARIZ) & U88226 & Arizona, United States (1982) & Arabis perennans \\
\hline P. monoica & AN024024 (ARIZ) & U88223 & Arizona, United States (1963) & Arabis sp. \\
\hline P. aberrans & $114408(\mathrm{COLO})$ & U88231 & Wyoming, United States (1951) & Smelowskia calycina \\
\hline P. aberrans & $189659(\mathrm{DAOM})$ & U88232 & Yukon, Canada (1982) & Smelowskia calycina \\
\hline P. codyi & $117853(\mathrm{DAOM})$ & U88233 & Yukon, Canada (1967) & Smelowskia borealis \\
\hline$P$. caricina & F00566 (UTC) & U88234 & Utah, United States (1993) & Carex rostrata \\
\hline P. drabae & 144964 (DAOM) & U88230 & Quebec, Canada (1967) & Draba arabisans \\
\hline P. drabae & 287901 (COLO) & U88229 & British Columbia, Canada (1954) & Draba longipes \\
\hline P. drabae & $163196(\mathrm{COLO})$ & U88228 & Finland (1958) & Draba hirta \\
\hline P. drabae & 82846 (COLO) & U88227 & Germany (1936) & Draba aizoides \\
\hline
\end{tabular}

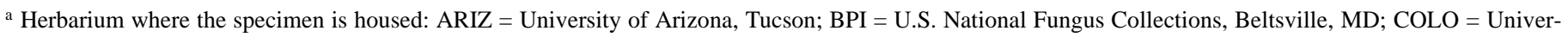
sity of Colorado, Boulder; DAOM = Biosystematics Research Centre, Ottawa, Ontario, Canada; UTC = Utah State University, Logan.

b Thlaspi alpestre $=$ T. montanum and Sisymbrium linifolium $=$ Schoenocrambe linifolia . 
body of the data, multibase-indel gaps were treated as missing data and taxa without gaps were treated as normal multistate DNA characters. To avoid double coding the single-base indels, we followed the coding procedure of Hibbett et al. (11).

Phylogenetic analyses of the sequence data were performed with the computer software PAUP (Phylogenetic Analysis Using Parsimony) 3.1.1 (21) on a Macintosh Quadra 800. To search for shortest trees, we used the HEURISTIC search option with random sequence addition, MULPARS (saving all shortest trees), COLLAPSING ZERO-LENGTH BRANCHES, TBR (tree bisection-reconnection), and STEEPEST DESCENT in effect. We repeated the analysis 100 times with random entry order of taxa to increase the chances of finding all islands of possible trees (19). We used bootstrap analyses (100 replicate heuristic searches with random taxon addition) to assess the degree of support for each monophyletic group on the strict consensus tree. All trees up to four steps longer than the shortest tree were saved with the FILTER TREES option, and strict consensus trees of these suboptimal solutions were used to obtain decay values for each branch (2). We assessed the amount of nonrandom structure in the data set using the RANDOM TREES (10,000 trees) option in PAUP. The $g_{1}$ statistic measures skewness of the frequency distribution of the random trees and can be used to evaluate the structure of the data (12,13). P. caricina (which occurs on Carex species) and $P$. drabae (which occurs on members of the family Brassicaceae) were used as outgroups for rooting the trees.

TABLE 2. Presence of different spore stages on herbarium specimens of Puccinia consimilis, P. thlaspeos, and Puccinia sp. from dyer's woad

\begin{tabular}{|c|c|c|c|c|}
\hline Species & Specimen & Aecia & Telia & Spermagonia \\
\hline \multirow[t]{16}{*}{ P. consimilis } & US-0058380 (BPI $)^{\mathrm{a}}$ & - & + & + \\
\hline & US-0058381 (BPI) & - & + & + \\
\hline & US-0058382 (BPI) & + & - & + \\
\hline & US-0058383 (BPI) & + & - & + \\
\hline & US-0058384 (BPI) & + & + & + \\
\hline & US-0058385 (BPI) & - & + & - \\
\hline & US-0058388 (BPI) & + & - & + \\
\hline & US-0058387 (BPI) & + & - & + \\
\hline & US-0058386 (BPI) & + & - & + \\
\hline & US-0058372 (BPI) & + & - & + \\
\hline & US-0058373 (BPI) & + & + & + \\
\hline & US-0058379 (BPI) & - & + & + \\
\hline & US-0058377 (BPI) & - & + & + \\
\hline & US-0058378 (BPI) & - & + & + \\
\hline & US-0058376 (BPI) & - & + & + \\
\hline & US-0058374 (BPI) & + & + & + \\
\hline \multirow[t]{16}{*}{ P. thlaspeos } & US-0107513 (BPI) & - & + & - \\
\hline & US-0107512 (BPI) & - & + & - \\
\hline & US-0107511 (BPI) & - & + & - \\
\hline & US-0107498 (BPI) & - & + & - \\
\hline & US-0107557 (BPI) & - & + & _- \\
\hline & US-0107556 (BPI) & - & + & - \\
\hline & AN025351 (ARIZ) & - & + & - \\
\hline & AN025352 (ARIZ) & - & + & + \\
\hline & AN025354 (ARIZ) & - & + & - \\
\hline & AN025356 (ARIZ) & - & + & + \\
\hline & AN025350 (ARIZ) & - & + & + \\
\hline & AN025353 (ARIZ) & - & + & - \\
\hline & AN025360 (ARIZ) & - & + & - \\
\hline & AN025359 (ARIZ) & - & + & - \\
\hline & AN025362 (ARIZ) & - & + & - \\
\hline & AN025361 (ARIZ) & - & + & - \\
\hline \multirow[t]{5}{*}{ Puccinia sp. } & AN025349 (UTC) & - & + & + \\
\hline & AN025348 (UTC) & - & + & + \\
\hline & AN025355 (UTC) & - & + & + \\
\hline & F00567 (UTC) & - & + & + \\
\hline & F00568 (UTC) & - & + & + \\
\hline
\end{tabular}

${ }^{\mathrm{a}}$ Herbarium where the specimen is housed: ARIZ $=$ University of Arizona, Tucson; BPI = U.S. National Fungus Collections, Beltsville, MD; and UTC $=$ Utah State University, Logan.

\section{RESULTS}

Host range and presence of spore stages. In 1993, 22 out of $27(81 \%)$ of the potted dyer's woad plants exposed to the woad rust fungus became infected; the other five plants died of unrelated causes. In 1994, 36 out of 52 (69\%) potted woad plants became infected. In both years, $T$. arvense, D. pinnata, B. napus, and $B$. campestris bolted and senesced while in pots at the exposure site, but never displayed any symptoms of infection. T. montanum and S. calycina from 1993 and 1994 never displayed any symptoms of rust infection after being overwintered and grown in pots through the second summer after exposure.

Seven of 16 herbarium specimens of $P$. consimilis examined had telia but no aecia, six had aecia but lacked telia, and only three had both stages. Spermagonia were observed on all except one of the herbarium specimens of $P$. consimilis (Table 2). Spermagonia were present on each specimen of the Puccinia on dyer's woad, but were found on only three of the 16 herbarium specimens of P. thlaspeos (Table 2).

Amplification and sequencing of DNA from herbarium specimens. We were able to amplify and sequence the entire ITS region from the three fresh specimens collected in northern Utah and from 20 additional specimens obtained from the herbaria listed in Table 1. Attempts to amplify and sequence DNA from other herbarium specimens were unsuccessful. DNA from several specimens could be amplified, but it was difficult to obtain sequences. In other cases, DNA from the specimens could not be amplified. The specimens that we used varied greatly in age, having been collected between 1889 and 1995. However, the age of the specimen did not appear to be directly related to whether its ITS could be successfully amplified and sequenced. For example, DNA extracted from specimens of $P$. consimilis (US-0058382) and P. thlaspeos (US-0107498) collected in 1889 and 1904, respectively, was amplified and sequenced (Table 1), whereas DNA from collections of $P$. thlaspeos (AN025350 and AN025358) made in 1949 and 1918, respectively, could not be amplified.

Alignment and phylogenetic analysis. The ITS region of the species of Puccinia studied contained enough characters to permit phylogenetic analysis. We aligned 712 nucleotide positions, including the internal $5.8 \mathrm{~s}$ region of 155 base pairs. Of the 712 positions, 194 were variable and 76 were potentially informative (more than two states shared by two or more samples). We detected 79 single-base indels of which 28 were potentially informative and 47 multiple-base indels of which 31 were potentially informative (Table 3). Complete unaligned sequences are available in GenBank under the accession numbers listed in Table 1.

Parsimony analysis yielded four shortest trees of 489 steps. The strict consensus of these trees (Fig. 2) shows several clades that are well supported by both bootstrapping and decay indices. The three specimens of the dyer's woad rust fungus included in the study were identical and formed a clade (designated clade 1) with the two specimens of $P$. consimilis (Fig. 2). Within this strongly supported clade (bootstrapping $=100 \%$, decay index $=4$ ), the specimens of $P$. consimilis formed a clade that was separate from dyer's woad rust with good bootstrap support (bootstrap support $=$ $67 \%$, decay index =2). P. monoica and some of the P. thlaspeos specimens were grouped into two additional clades (designated 2 and 4 ) that were strongly supported. Clade 4 (bootstrap support $=$ $99 \%$, decay index $=4$ ) included one specimen of $P$. monoica and two of $P$. thlaspeos. Clade 2 (bootstrap support $=91 \%$, decay index 4) included two specimens of $P$. thlaspeos and two of $P$. monoica. In this case, $P$. monoica and $P$. thlaspeos are on separate branches that are each strongly supported as being monophyletic. Both branches have bootstrap support of $100 \%$ and decay indices of 4 . Clade 3 is also strongly supported (bootstrap support = $100 \%$, decay index $=4$ ) and is comprised of two specimens from northern Canada, one representing $P$. aberrans and the other $P$. codyi. An additional specimen of $P$. aberrans from the western 
United States was loosely associated with this clade, but the association was weakly supported (Fig. 2). One of the fungi used as an outgroup, $P$. caricina, was widely divergent from the Puccinia species occurring on members of the family Brassicaceae. The specimens of $P$. drabae formed a polyphyletic group that was also widely divergent from the other species of Puccinia that occur on the family Brassicaceae.

\section{DISCUSSION}

The sequence analysis indicates that the dyer's woad rust fungus is closely related to $P$. consimilis rather than to $P$. thlaspeos. $P$. consimilis is an autoecious rust that systemically infects members of the family Brassicaceae and is known to occur only in the Rocky Mountains of western North America. The localized occurrence of $P$. consimilis overlaps with the distribution of dyer's woad, and it is possible that a strain of $P$. consimilis switched from its indigenous hosts to dyer's woad. New races of some rusts may develop quite readily. For example, Little and Manners (16) showed that, in a single experiment in which susceptible host plants were inoculated with two races of $P$. striiformis, new races were easily isolated from diseased plants. Ten percent of the single-spore cultures isolated from the infected hosts were new races that were subsequently shown to be stable for a period of at least 1 year after the experiment. In addition, Burdon et al. (3) found evidence that hybridization between formae speciales of $P$. graminis can produce strains that are virulent on new host species.

Although the teliospores of $P$. consimilis closely resemble those of the dyer's woad rust fungus, $P$. consimilis reportedly differs by having aecia and telia that occur simultaneously on a single host (1). However, only three of the specimens of $P$. consimilis studied had both stages present, and nearly half had telia but no aecia. Because the presence of both aecia and telia on the same host is a primary character separating $P$. consimilis from related Puccinia species, there is little to distinguish the specimens of $P$. consimilis that lack aecia from the fungus on dyer's woad. In addition, spermagonia were observed on almost all of the herbarium specimens of $P$. consimilis. Spermagonia are a conspicuous feature of Puccinia infections observed on dyer's woad plants in the field, and they were present on each herbarium specimen of Puccinia on dyer's woad listed in Table 2.

The failure of the Puccinia from dyer's woad to produce symptoms on several known hosts of $P$. thlaspeos is evidence that the woad rust is not $P$. thlaspeos. Like the specimens of $P$. consimilis, which lack aecia, very little distinguishes the woad rust fungus from $P$. thlaspeos. The teliospores of both fungi are very similar, both lack aecia and uredia and both cause systemic infections on crucifers. However, one morphological difference is that plants infected with $P$. thlaspeos are reported to lack spermagonia (1), and spermagonia were lacking on most of the herbarium specimens of $P$. thlaspeos examined (Table 2 ). The consistent presence of spermagonia on rust-infected dyer's woad is further evidence that the dyer's woad rust is not P. thlaspeos.

Among the six specimens of $P$. thlaspeos studied, only two (AN025352 and AN025354) grouped in the same clade. In fact, the sequence from one specimen of $P$. thlaspeos (US-0107498) appears with $P$. drabae on the consensus tree presented in Figure 2 . The remaining sequences obtained for specimens of $P$. thlaspeos are also quite divergent, indicating that this taxon is polyphyletic. Our data do not support the hypothesis that $P$. thlaspeos and $P$. monoica are correlated species $(1,5)$, even though sequences from some of the specimens of $P$. thlaspeos appear on clades with $P$. monoica. However, the morphologies of specimens of $P$. thlaspeos used in this study, including US-0107498, were very similar and fit published descriptions of this species. Because $P$. thlaspeos is microcyclic, there are relatively few characters that can be used to delimit this species. The only taxonomic characters available are either the host plant on which the fungus grows or teliospore characteristics such as spore dimensions, cell wall thickness, lack of ornamentation, location of pores, and length and persistence of the pedicel. More species may exist within taxa like $P$. thlaspeos than can be detected using this relatively limited set of morphological characters. This might also characterize $P$. drabae, which our data indicate is another polyphyletic taxon. The members of this species have ornamented teliospores (Fig. 1) and are widely divergent from the smooth-spored Puccinia species examined in this study. $P$. drabae is also microcyclic and, as is the case for P. thlaspeos,

TABLE 3. Comparison of character $\operatorname{codes}^{\mathrm{a}}$ from aligned sequences of ITS1, ITS2, and the $5.8 s$ gene of Puccinia species on crucifers

\begin{tabular}{|c|c|c|}
\hline Species & Specimen & Coding characters \\
\hline Puccinia sp. & F00568 & 10101100000010001010010111000001111110010101111 \\
\hline Puccinia sp. & F00567 & 10101100000010001010010111000001111110010101111 \\
\hline Puccinia sp. & AN025349 & 10101100000010001010010111000001111110010101111 \\
\hline P. consimilis & US-0058385 & 10101100000010001010010111000001111110010101111 \\
\hline P. consimilis & US-0058382 & 10101100000010001010010111000001111110010101111 \\
\hline P. thlaspeos & US-0107498 & 10111111110010010111011111001011011110100110111 \\
\hline P. thlaspeos & US-0107511 & 10111000000010010110010111000001110110010101110 \\
\hline P. thlaspeos & US-0107513 & 10111100000011111110010110101111111110010111101 \\
\hline P. thlaspeos & AN025351 & 10111100000010111110010111000001111110010111111 \\
\hline P. thlaspeos & AN025352 & 10111110000010111110010111000001111110010111111 \\
\hline P. thlaspeos & AN025354 & 10111110000010111110010111000001111110010111111 \\
\hline P. monoica & AN024024 & 10111110000010111110010111000001111110010111111 \\
\hline P. monoica & AN024025 & 10111000000010100110010111000001110110010110100 \\
\hline P. monoica & AN024026 & 10111000000010001010010111000001111110010100011 \\
\hline P. monoica & AN024032 & 10111000000010001010010111000001111110010100011 \\
\hline P. drabae & 82846 & 10111111110010010111011111001011011110100110111 \\
\hline P. drabae & 163196 & 10111111111110010111011111001011011110110110111 \\
\hline P. drabae & 287901 & 10111110100010010111011111001011011110110110111 \\
\hline P. drabae & 144964 & 11111010000010000000110111111111101110101111111 \\
\hline P. aberrans & 114408 & 10111100000010011000010111000001111110010111110 \\
\hline P. aberrans & 189659 & 10111100000011111110010111000001111110010111111 \\
\hline P. codyi & 117853 & 10111100000010111111010111000001111110010111111 \\
\hline P. caricina & F00566 & 00000111000100111111100001001000111001110011111 \\
\hline
\end{tabular}

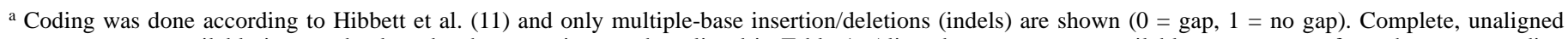
sequences are available in gene bank under the accession numbers listed in Table 1. Aligned sequences are available upon request from the corresponding author. 


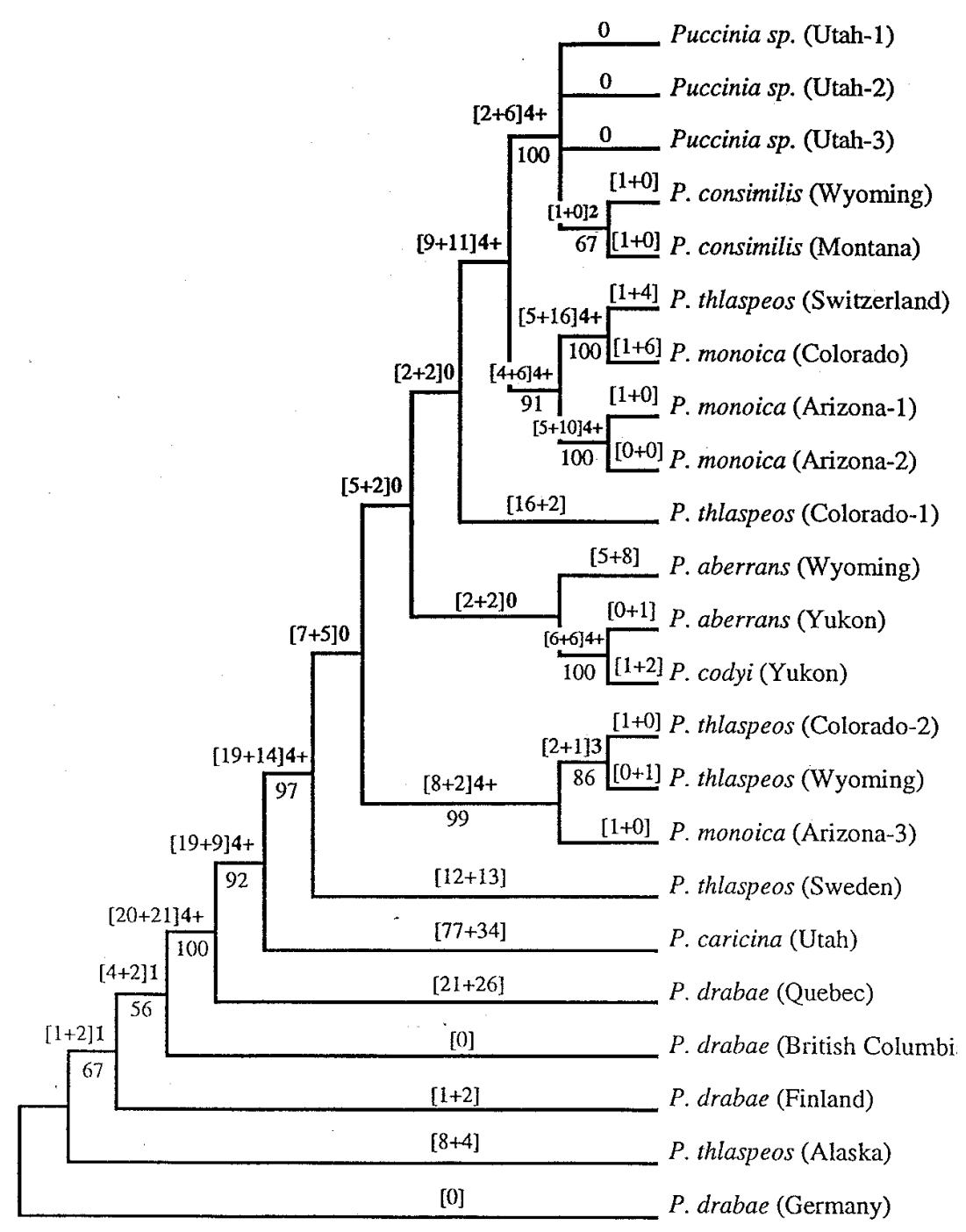

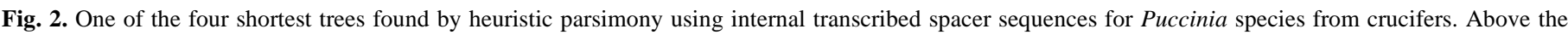

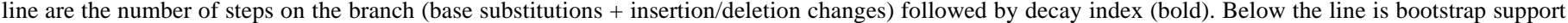
for the branch. Table 1 has more information on specimens.

there are a limited number of morphological characters available for species circumscription.

An alternative explanation for the apparent polyphyletic nature of $P$. thlaspeos and $P$. drabae is that the phylogeny of the ITS sequences is incongruent with the phylogeny of the taxa. This incongruence could come about either through transfer of sequences from one taxon to another by hybridization or by gene duplication at some point along the lineage of the modern taxa. Lineage sorting is another mechanism that could lead to an incongruence between trees for species and sequences (6). If this were the case, individual sequences from a polymorphic ancestral rust fungus could end up being distributed among otherwise unrelated modern taxa. When only a single sequence is studied, this would lead to an incorrect assessment of species relationships. Thus, sequences of additional genes need to be analyzed to clarify further the phylogeny of the fungi examined in this study. The inclusion of other species of Puccinia, such as P. trabutii found on the family Brassicaceae in Europe, would also improve our understanding of these fungi.

Another possibility is that the fungus from dyer's woad was introduced to North America along with dyer's woad. We consider this to be unlikely, since the only rust fungus known to occur on $I$. tinctoria in Europe is $P$. trabutii (9). P. trabutii is heteroecious and macrocyclic and is quite distinct from the microcyclic, autoecious fungus occurring on dyer's woad in North America. Because rusts resembling $P$. thlaspeos have not been reported to occur on $I$. tinctoria in its native habitat, the Puccinia species found on it in
North America is probably indigenous. This is supported by the sequence data presented in this article, indicating that there is a close relationship between $P$. consimilis, which is found only on crucifers in western North America, and the Puccinia, which also occurs on I. tinctoria in the western United States.

Because introduced plant pathogens have a history of causing serious disease epidemics (20), the use of an introduced pathogen as a biological control agent must be approached carefully. Since our data indicate that the Puccinia species attacking dyer's woad is native to North America, this fungus is unlikely to cause disease epidemics on indigenous plants if used as an agent for the biological control of dyer's woad. Our data also indicate that it does not cause disease on canola (both B. napus and B. campestris). This finding is important, because the use of this fungus as a biological control agent would require that it not be pathogenic on related crop plants.

\section{ACKNOWLEDGMENTS}

This research was supported by The Utah Department of Agriculture, Utah State University, and the USDA Rangeland Research Program. This article is Utah Agricultural Experiment Station paper 4983. We thank the following herbaria for lending specimens for use in this work: University of Arizona, Tucson; U.S. National Fungus Collections, Beltsville, MD; University of Colorado, Boulder; Biosystematics Research Centre, Ottawa, Ontario, Canada; and Utah State University, Logan. We thank D. S. Hibbett for his helpful advice regarding coding methods. 


\section{LITERATURE CITED}

1. Arthur, J. C. 1934. Manual of the Rusts in the United States and Canada. The Science Press Printing Co., Lancaster, PA.

2. Bremer, K. 1988. The limits of amino acid sequence data in angiosperm phylogenetic reconstruction. Evolution 42:795-803.

3. Burdon, J. J., Marshall, D. R., and Luig, N. H. 1981. Isozyme analysis indicates that a virulent cereal rust pathogen is a somatic hybrid. Nature 293:565-566.

4. Callihan, R. H., Dewey, S. A., Patton, J. E., and Thill, D. C. 1984. Distribution, biology and habitat of dyers woad (Isatis tinctoria L.) in Idaho. J. Idaho Acad. Sci. 20:18-32.

5. Cummins, G. B., and Hiratsuka, Y. 1983. Illustrated Genera of the Rust Fungi. The American Phytopathological Society, St. Paul, MN.

6. Doyle, J. J. 1992. Gene trees and species trees: Molecular systematics as one-character taxonomy. Syst. Bot. 17:144-163.

7. Farr, D. F., Bills, G. F., Chamuris, G. P., and Rossman, A. Y. 1989. Fungi on Plants and Plant Products in the United States. The American Phytopathological Society, St. Paul, MN.

8. Gardes, M., and Bruns, T. D. 1993. ITS primers with enhanced specificity for basidiomycetes-Application to the identification of mycorrhizae and rusts. Mol. Ecol. 2:113-118.

9. Gäumann, E. 1959. Beiträge zur Kryptogamenflora der Schweiz. Band XII. Die Rostpilz Mitteleuropas. Büchler \& Co., Bern, Switzerland.

10. Hasan, S., and Wapshere, A. J. 1973. The biology of Puccinia chrondrillina a potential biological control agent of skeleton weed. Ann. Appl. Biol. 74:325-332.

11. Hibbett, D. S., Fukumasa-Nakai, Y., and Donoghue, M. J. 1995. Phylogenetic diversity in shiitake inferred from nuclear ribosomal DNA sequences. Mycologia 87:618-638.

12. Hillis, D. M., and Huelsenbeck, J. P. 1992. Signal, noise, and reliability in molecular phylogenetic analyses. J. Hered. 83:189-195.

13. Källersjö, M., Farris, J. S., Kluge, A. G., and Bult, C. 1992. Skewness and permutation. Cladistics 8:275-287.

14. Kropp, B. R., Albee, S., Flint, K. M., Zambino, P., Szabo, L., and Thomson,
S. V. 1995. Early detection of systemic rust infections of dyers woad (Isatis tinctoria) using the polymerase chain reaction. Weed Sci. 43:467-472.

15. Kropp, B. R., Hansen, D., Flint, K. M., and Thomson, S. V. 1996. Artificial inoculation and colonization of dyer's woad (Isatis tinctoria) by the systemic rust fungus Puccinia thlaspeos. Phytopathology 86:891-896.

16. Little, R., and Manners, J. G. 1969. Somatic recombination in yellow rust of wheat (Puccinia striiformis). I. The production and possible origin of two new physiological races. Trans. Br. Mycol. Soc. 53:251-258.

17. Liu, Z., Szabo, L. J., and Bushnell, W. R. 1993. Molecular cloning and analysis of abundant and stage-specific mRNAs from Puccinia graminis. Mol. Plant-Microbe Interact. 6:84-91.

18. Lovic, B. R., Dewey, S. A., Thomson, S. V., and Evans, J. O. 1988. Puccinia thlaspeos-A possible biocontrol agent for dyers woad. Proc. West. Soc. Weed Sci. 41:55-57.

19. Maddison, W. P. 1991. The discovery and importance of multiple islands of most-parsimonious trees. Syst. Zool. 40:315-328.

20. Schumann, G. L. 1991. Plant Diseases: Their Biology and Social Impact. The American Phytopathological Society, St. Paul, MN.

21. Swofford, D. L. 1993. PAUP: Phylogenetic analysis using parsimony, version 3.1.1. Illinois Natural History Survey, Champaign, IL.

22. Te Beest, D. O., Yang, X. B., and Cisar, C. R. 1992. The status of biological control of weeds with fungal pathogens. Annu. Rev. Phytopathol. 30:637-657.

23. Varga, W. A., and Evans, J. O. 1978. Dyer's woad: From cultivated to cursed. Utah Sci. 39:87-89.

24. White, T. J., Bruns, T., Lee, S., and Taylor, J. 1990. Amplification and direct sequencing of fungal ribosomal RNA genes for phylogenetics. Pages 315-322 in: PCR Protocols a Guide to Methods and Applications. M. A. Innis, D. H. Gelfand, J. J. Sninsky, T. J. White, eds. Academic Press, Inc., New York.

25. Whitehouse, E. H., and Spears, T. 1991. A simple method for removing oil from cycle sequencing reactions. Biotechniques 11:616.

26. Zambino, P. J., and Szabo, L. J. 1993. Phylogenetic relationships of selected cereal and grass rusts based on rDNA sequence analysis. Mycologia 85:401-414. 